\title{
Long Term Evaluation of Local Surface Water Quality
}

\author{
Gija Geme, Casey O'Hara, Kara O'Neal
}

\author{
Southern Arkansas University, 100 E. University, MSC 9289, Magnolia, AR 71753
}

\begin{abstract}
Quality assurance and effective quality control procedures are necessary for adequate biological monitoring of aquatic ecosystems. It is through routine quantitative and qualitative sampling of specific environmental parameters that we are able to determine the quality and validity of our measurements. Our goal, along with the mission of the L. A. Logan Biological Field Station at Lake Columbia (Columbia Co., AR), is to monitor important parameters regarding the quality of our water resources and recreational areas.
\end{abstract}

Water samples from Lake Columbia, AR were taken every week and analyzed for $\mathrm{pH}$, dissolved oxygen, nitrate and chloride ions, total phosphorus, total solids, bacteria (E.coli, total coliform, and fecal coliform), alkalinity, turbidity, conductivity, and ammonia. Water temperature was also measured and recorded during sampling. The results were averaged monthly and submitted to the Dean of the College of Science and Engineering and they were posted on Southern Arkansas University's (SAU's) website.

Different analytical probes and simple analytical methods were used to quantitate analytes. The samples were taken weekly and then averaged to report average monthly data. Water monitoring started in 2014 and will continue indefinitely.

Keywords: surface water, recreational water, water quality, microbiology, nutrients

\section{INTRODUCTION}

Good water quality is necessary not only for humans but also for the well-being of nature and the overall development of local economics. The quality of water reservoirs is needed to be as close to the natural levels as possible so the living organisms can have all the necessary nutrients and thus they would be able to survive. It will also ensure the stability of the water ecosystems and its good functionality.Lake ecosystems are made up of physical, chemical and biological properties contained within these water bodies. Lakes may contain fresh or salt water (in arid regions). They may be shallow or deep, permanent or temporary. Lakes of all types share many ecological and biogeochemical processes [1].

Pollution affects water quality in lakes. Pollution may originate from industry, agriculture or municipalities and thus possible pollutants may be herbicides, pesticides, sewage and litter. There are various types of water pollution based on the various causes of water pollution. Various classifications can be made based on the origin of pollution. One of the pollution sources and probably the most common one is a chemical pollution. The chemical pollution is caused by crude oil, fertilizers, chlorinated solvents, petroleum solvents, antibiotics, metals, and pesticides. The other pollution source can be radiological which occurs when radioactive materials enters the water reservoirand thus causes pollution. Finally, biological pollution is related to various microorganisms and algae which causes pollution. Mainly this type of pollution is caused by decaying organic material in water and very often animal wastes [2].

Lake Columbia is a 3,000-acre impoundment stretching for six miles along Beech Creek about six miles northwest of Magnolia in south central Arkansas. It was constructed in 1986 by the Arkansas Game and Fish Commission, which provides three concrete boat ramps, two with accompanying courtesy boat docks and fishing piers. A picnic area is available in a day-use area on the lake's south shore. The lake and campgrounds are owned and managed by the Columbia County Rural Development Authority. The lake is divided into four zones, including a small area off-limits to unauthorized visitors. Fishing is allowed on the rest of the lake, and the western half is also open for pleasure-boating and water sports [3]. 
Good water quality of Lake Columbia is significant for two reasons: 1) Lake is used as a drinking water source for a local community of around 11,000 people and2) During summer months, the lake is used for swimming and other recreational activities.

Lake water quality can be monitored for its microbiological properties and chemical properties. The microbiological properties include total coliform, e. coli, and fecal coliform, dissolved oxygen, and biochemical oxygen demand. The chemical properties include $\mathrm{pH}$, different ions such as chloride and nitrate, total solids, total phosphorus, alkalinity and hardness $[4,5]$.

The different parameters can be measured with simple sensors, sophisticated instrumentation or simple wet lab chemistry methods. To better disseminate collected data, the SAU website sustained by the College of Science and Engineering was used to present the data.

\section{MATERIALS AND METHODS}

\subsection{Sample Collection}

Water samples were taken every week from the same location on Lake Columbia, AR. Water temperature and $\mathrm{pH}$ were measured by the analytical sensors at the location. The rest of the samples were collected in the appropriate containers and transferred to the lab for analysis. The microbiological samples and nitrate ion samples were analyzed immediately upon return to the lab. If samples could not be analyzed immediately, it was preserved with nitric acid, stored in the refrigerator and analyzed at a later time.

\subsection{Sample Analysis}

The USEPA methods were used for analysis of each analyte. The Hach probes were used to measure ammonia, $\mathrm{pH}$, dissolved oxygen, chloride, nitrate, conductivity and temperature [6]. The calibration curves were prepared for ammonia, nitrate and chloride analytes. The biochemical oxygen demand (BOD) test was performed by incubating a sealed lake water sample (or prepared dilution) for the standard five-day period and then determining the change in dissolved oxygen content. The BOD value was then calculated from the results of the dissolved oxygen tests.

Bacterial colonies were recovered using the membrane filtration method. M-Fc broth was used to recover total coliforms and m-ColiBlue 24 broth was used to recover total and E.coli coliforms. Colonies were counted after a 24 hour incubation period. Total solids were measured gravimetrically. A well-mixed sample was evaporated in a weighed dish and dried to constant weight in an oven at 103 to $105^{\circ} \mathrm{C}$. The increase in weight over that of the empty dish represents the total solids in lake water. Total phosphorus was analyzed by a test and tube method which required digestion and spectrometric detection. Alkalinity was determined by a titration method. An unaltered sample was titrated to an electrochemically determined end point of $\mathrm{pH} 4.5$. Turbidity method was based on a comparison of the intensity of light scattered by the sample under defined conditions with the intensity of light scattered by a standard reference suspension under the same conditions. The higher the intensity of scattered light, the higher the turbidity.

\section{RESULTS AND DiSCUSSION}

Lake Columbia water samples were analyzed for alkalinity, ammonia, BOD, chloride, conductivity, dissolved oxygen, hardness, nitrate, $\mathrm{pH}$, temperature, total phosphorus, total solids, and turbidity. The overall data is presented in Table 1 . The data represents the average monthly data.

\subsection{Total Coliform}

Bacterial total coliforms are used as an indicator of water pollution. Their presence in a water source indicates that pathogenic organisms of fecal origin may be present. Lake Columbia has high number of total coliform bacteria present throughout the year with higher colony counts present in summer, particularly in May and June, total coliforms ranged from 39-1310 colonies.

\subsection{E. coli}

E. coli coliforms are a subset of fecal coliforms. There are both pathogenic strains and non-pathogenic strains of E. coli. These bacteria originate from the wastes of animals or humans. Thus, high numbers of $E$. coli in a lake could come from septic systems, runoff from barnyards, or from wildlife. Lakes used for swimming and other recreation should have less than 126 colonies of $E$. coli bacteria per 100 
$\mathrm{mL}$ of water [7]. The E. coli coliforms were not detected in some samples and some samples had 24 E. coli colonies. The higher colonies of E. coli were observed in summer months - May, June and July.

\subsection{Fecal Coliform}

Fecal coliforms are a subset of total coliforms. They are found in in the intestinal tract of warmblooded animals; however, the presence of fecal coliforms does not always mean that pathogenic bacteria are present. The presence of fecal coliform bacteria in aquatic environments indicates that the water has been contaminated with the fecal material of man or other animals. Fecal coliform bacteria can enter rivers through direct discharge of waste from mammals and birds. At the time this occurs, the source water may be contaminated by pathogens or disease producing bacteria or viruses, which can also exist in fecal material. Some waterborne pathogenic diseases include ear infections, dysentery, typhoid fever, viral and bacterial gastroenteritis, and hepatitis A. The presence of fecal coliform tends to affect humans more than it does aquatic creatures, though not exclusively. While these bacteria do not directly cause disease, high quantities of fecal coliform bacteria suggest the presence of disease causing agents. The presence of fecal contamination is an indicator that a potential health risk exists for individuals exposed to this water [8]. The fecal coliform colonies ranged from 1-65 colonies, the higher number of colonies were present during summer months were water temperature is also high.

\subsection{Ammonia}

Ammonia is present naturally in surface waters. Its concentration generally is low in groundwaters because it adsorbs to soil particles and clays and is not leached readily from soils. It is produced largely by deamination of organic nitrogen containing compounds and by hydrolysis of urea and is a significant indication of poor water quality. Ammonia concentrations encountered in water vary from less than $10 \mu \mathrm{g} / \mathrm{L}$ ammonia nitrogen/L in some natural surface and groundwaters [9].It is toxic to fish and other aquatic life, places a high oxygen demand on the receiving waters, and provides nutrients that can lead to algal blooms. Ammonia concentrations ranged from $0.0154-2.52 \mathrm{mg} / \mathrm{L}$, spiking in the month of May.

\subsection{Nitrate-Nitrogen and Total Phosphorus}

Nitrogen and phosphorus are nutrients that may cause increased growth of aquatic plants and algae. Nitrate-nitrogen concentrations above $3 \mathrm{mg} / \mathrm{L}$ and any detectable amounts of total phosphorus may be indicative of pollution from fertilizers, manures or other nutrient-rich wastes [7]. The nitrate concentrations ranged from $0.035-10.7 \mathrm{mg} / \mathrm{L}$, having particularly high concentrations in year of 2015 . The total phosphorus concentrations ranged from 0.06-0.29 mg/L, reaching the highest values in May and June.

\section{6.pH}

The $\mathrm{pH}$ of a pond or lake should generally fall between 6.0 and 9.0. Different types of fish tolerate different $\mathrm{pH}$ levels but, in general, most fish will do better in ponds with a $\mathrm{pH}$ near 7.0. Ponds with a $\mathrm{pH}$ less than 6.0 may result in stunted, reduced or even absent fish populations [7]. The $\mathrm{pH}$ ranged from 6.46-7.85, with slightly basic $\mathrm{pH}$ during the summer period.

\subsection{Alkalinity}

Alkalinity refers to the capability of water to neutralize acid. Alkalinity is important for fish and aquatic life because it protects or buffers against rapid $\mathrm{pH}$ changes. For the protection of aquatic life, the buffering capacity should be at least $20 \mathrm{mg} / \mathrm{L}$ [10]. Mostly alkalinity stayed above $20 \mathrm{mg} / \mathrm{L}$ range with lower alkalinity in winter months of 2015.

\subsection{Total Solids}

Solids refer to matter suspended or dissolved in water. Solids may affect water or effluent quality adversely in a number of ways. Waters with high dissolved solids generally are of inferior palatability and may induce an unfavorable physiological reaction in the transient consumer. Highly mineralized waters also are unsuitable for many industrial applications. Solids analyses are important in the control of biological processes. "Total solids" is the term applied to the material residue left in the vessel after evaporation of a sample and its subsequent drying in an oven at a defined temperature. 
Total solids includes "total suspended solids", the portion of total solids retained by a filter, and "total dissolved solids," the portion that passes through the filter. . The increase in weight over that of the empty dish represents the total solids in water in the range up to $20,000 \mathrm{mg} / \mathrm{L}$. The total solids ranged from 23.5-66.8, with the highest concentrations reaching in the month of May but well below the $20,000 \mathrm{mg} / \mathrm{L}$ level.

\subsection{Conductivity}

Conductivity is a measure of the ability of an aqueous solution to carry an electric current. The conductivity depends on the total ion concentration and the temperature when the measurement is taken [9]. Conductivity in lake water can be used as an estimate for remaining dissolved solids in water. This is of particular interest since it can be used as pollution indicator. For example, lakes with possible pollution from the runoff will have higher concentration of ions and thus higher conductivity values. However, evaporation of surface water from lake should also be taken into account since higher dissolved solids will be observed and thus higher conductivity values will be recorded. The conductivity did not change significantly during the time period monitored, although water temperature changed significantly.

\subsection{Turbidity}

Clarity of water is important in producing products destined for human consumption and in many manufacturing operations. Potable water treatment plants drawing from a surface water source commonly rely on fluid-particle separation processes such as sedimentation and filtration to increase clarity and insure an acceptable product. The clarity of a natural body of water is an important determinant of its condition and productivity. Turbidity in water is caused by suspended and colloidal matter such as clay, silt, finely divided organic and inorganic matter, and plankton and other microscopic organisms.The fish start showing signs of stress if turbidity reaches between 5 and 10 NTUs and they are exposed to this water for only hours [11]. The turbidity stayed below 5 NTUs, there were two occasions when higher values were observed: March of 2015 - 9.95 NTUs and May of 2016 - 5.07 NTUs.

\subsection{Dissolved Oxygen}

Dissolved oxygen measures how much oxygen is readily present in the water. In order to sustain aquatic life, dissolved oxygen levels must be above $1.0 \mathrm{mg} / \mathrm{L}$. Levels that are below $5.0 \mathrm{mg} / \mathrm{L}$ put aquatic life under stress. The dissolved oxygen ranged from 8 to $11 \mathrm{mg} / \mathrm{L}$, well above the necessary standards.

\subsection{BOD}

Biochemical oxygen demand, or BOD, measures the amount of oxygen consumed by microorganisms in decomposing organic matter in stream water. BOD also measures the chemical oxidation of inorganic matter (i.e., the extraction of oxygen from water via chemical reaction). The rate of oxygen consumption in a lake is affected by a number of variables: temperature, $\mathrm{pH}$, the presence of certain kinds of microorganisms, and the type of organic and inorganic material in the water.

BOD directly affects the amount of dissolved oxygen in lakes. The greater the BOD, the more rapidly oxygen is depleted in the lakes. This means less oxygen is available to higher forms of aquatic life. The consequences of high BOD are the same as those for low dissolved oxygen: aquatic organisms become stressed, suffocate, and die.

Sources of BOD include leaves and woody debris; dead plants and animals; animal manure; effluents from pulp and paper mills, wastewater treatment plants, feedlots, and food-processing plants; failing septic systems; and urban storm water runoff [9]. The BOD ranged from 0 to $6.67 \mathrm{mg} / \mathrm{L}$.

\subsection{Chloride}

Chlorides are present in both fresh and salt water, and are essential elements of life. High chloride concentrations in freshwater can harm aquatic organisms by interfering with osmoregulation, the biological process by which they maintain the proper concentration of salt and other solutes in their bodily fluids. Difficulty with osmoregulation can hinder survival, growth, and reproduction. Typically acceptable chloride concentration exposure limits for freshwater organisms are set at $860 \mathrm{ppm}$ to prevent acute (immediate) exposure effects and at $230 \mathrm{ppm}$ to prevent chronic (long-term) exposure 
effects. For drinking water, the limit has been set a maximum contaminant level of 250 ppm chloride, which is the point at which water starts to taste salty [12]. The chloride concentrations ranged from 0 $7 \mathrm{mg} / \mathrm{L}$, well within acceptable range.

Table1. The water quality data 2014-2016

2014 Data

\begin{tabular}{|l|c|c|c|c|c|c|c|c|c|c|c|c|}
\hline Analyte & Jan & Feb & Mar & Apr & May & Jun & Jul & Aug & Sep & Oct & Nov & Dec \\
\hline Chloride (mg/L) & 3.47 & 3.64 & 4.17 & 3.45 & 3.25 & 5.55 & 5.54 & 2.90 & 2.32 & 2.75 & 3.8 & 4.52 \\
\hline $\begin{array}{l}\text { Conductivity } \\
\text { uSS/cm) }\end{array}$ & 54.37 & 52.70 & 59.53 & 57.75 & 59.80 & 56.13 & 56.52 & 59.23 & 61.35 & 59.85 & 57.83 & 57.75 \\
\hline $\begin{array}{l}\text { Dissolved } \\
\text { Oxygen (mg/L) }\end{array}$ & 10.01 & 9.68 & 10.22 & 10.43 & 8.61 & 7.40 & 7.47 & 7.52 & 9.70 & 11.34 & 10.71 & 10.25 \\
\hline $\begin{array}{l}\text { Hardness } \\
\text { (mgCaCO3/L) }\end{array}$ & 0.099 & 0.183 & 0.986 & 6.89 & 7.54 & 8.638 & 9.129 & 7.328 & 10.013 & 6.621 & 1.495 & 3.178 \\
\hline $\begin{array}{l}\text { Nitrate (mg/L) } \\
\text { pH (S.U.) }\end{array}$ & 1.988 & 1.639 & 1.037 & 0.4668 & 1.506 & 5.045 & 0.2221 & 0.2953 & 0.1135 & 0.3313 & 0.5522 & 0.3978 \\
\hline $\begin{array}{l}\text { Temperature } \\
\text { (⿳⺈⿴囗十一) }\end{array}$ & 4.59 & 6.46 & 7.07 & 7.12 & 7.57 & 7.78 & 7.65 & 7.69 & 7.69 & 7.54 & 7.45 & 7.73 \\
\hline $\begin{array}{l}\text { Total } \\
\text { Phosphorus } \\
\text { (mg/L) }\end{array}$ & 0.18 & 0.06 & 0.13 & 0.30 & 0.18 & 0.27 & 0.29 & 0.26 & 0.23 & 0.16 & 0.09 & 0.09 \\
\hline $\begin{array}{l}\text { Total Solids } \\
\text { (mg/L) }\end{array}$ & 36.0 & 23.5 & 47.8 & 63.0 & 57.2 & 65.5 & 52.2 & 51.3 & 50.8 & 51.1 & 53.1 & 49.2 \\
\hline Turbidity(NTU) & 2.04 & 2.34 & 1.78 & 1.83 & 2.14 & 2.35 & 2.41 & 2.67 & 3.43 & 2.26 & 2.78 & 2.13 \\
\hline
\end{tabular}

\begin{tabular}{|l|c|c|c|c|c|c|c|c|c|c|c|c|}
\hline Analyte & Jan & Feb & Mar & Apr & May & Jun & Jul & Aug & Sep & Oct & Nov & Dec \\
\hline Total Coliforms & 378 & 473 & 193 & 330 & 456 & 530 & 898 & 553 & 503 & 350 & 990 & 39 \\
\hline Fecal Coliforms & 4 & 3 & 4 & 2 & 6 & 5 & 7 & 10 & 14 & 2 & 5 & 1 \\
\hline E. coli Coliforms & $<1$ & $<1$ & $<1$ & $<1$ & 10 & 3 & $<1$ & $<1$ & $<1$ & $<1$ & $<1$ & $<1$ \\
\hline
\end{tabular}

2015 Data

\begin{tabular}{|l|c|c|c|c|c|c|c|c|c|c|c|c|}
\hline Analyte & Jan & Feb & Mar & Apr & May & Jun & Jul & Aug & Sep & Oct & Nov & Dec \\
\hline Alkalinity (mgCaCO $\mathbf{3} / \mathbf{L})$ & 7.0 & 13.2 & 6.7 & 9.0 & 31 & 40 & 40 & 30 & 8.0 & 40 & 30 & 40 \\
\hline Ammonia (mg/L) & 0.23 & 0.26 & 0.14 & 0.20 & 2.5 & 0.13 & 0.098 & 0.083 & 0.085 & $<$ det & 0.015 & 0.018 \\
\hline BOD (mg/L) & 6.67 & 5.98 & $<2.00$ & $<2.00$ & $<2.00$ & 3.2 & $<2.00$ & 2.02 & 3.72 & 3.37 & $<2.00$ & $<2.00$ \\
\hline Chloride (mg/L) & 6.3 & 4.6 & 1.1 & 3.8 & 1.3 & 5.1 & 0.13 & 0.24 & 0.13 & 0.093 & 0.053 & 0.21 \\
\hline Conductivity (uS/cm) & 61.7 & 60.2 & 49.1 & 49.2 & 48.3 & 49.6 & 43.3 & 51.2 & 49.5 & 50.6 & 46.8 & 45.2 \\
\hline Dissolved Oxygen (mg/L) & 10.93 & 9.82 & 8.09 & 9.98 & 8.71 & 8.73 & 8.79 & 8.57 & 8.46 & 8.13 & 8.73 & 9.19 \\
\hline Nitrate (mg/L) & 1.99 & 4.11 & 0.133 & 0.806 & 0.035 & 4.89 & 10.7 & 9.99 & 9.81 & 9.86 & 7.46 & 6.55 \\
\hline pH (S.U.) & 7.76 & 7.68 & 7.60 & 6.80 & 6.94 & 7.68 & 7.57 & 7.85 & 7.05 & 7.28 & 6.26 & 6.82 \\
\hline Temperature (0) C) & 8.00 & 9.50 & 12.8 & 22.3 & 24.8 & 29.3 & 31.6 & 31.1 & 27.9 & 25.5 & 15.4 & 12 \\
\hline Total Phosphorus (mg/L) & 0.07 & 0.07 & 0.1 & 0.1 & 0.1 & 0.08 & 0.09 & 0.1 & 0.04 & 0.04 & 0.08 & 0.05 \\
\hline Total Solids (mg/L) & 51.7 & 40.5 & 52.2 & 66.8 & 57.0 & 49.8 & 50.8 & 28.3 & 31.7 & 40.3 & 47 & 27.5 \\
\hline Turbidity(NTU) & 1.75 & 1.64 & 9.95 & 4.39 & 3.08 & 2.35 & 1.64 & 2.38 & 2.1 & 3.03 & 1.94 & 1.87 \\
\hline
\end{tabular}

\begin{tabular}{|l|c|c|c|c|c|c|c|c|c|c|c|c|}
\hline Analyte & Jan & Feb & Mar & Apr & May & Jun & Jul & Aug & Sep & Oct & Nov & Dec \\
\hline Total Coliforms & 333 & 235 & 127 & 1,320 & 650 & 1,050 & 513 & 647 & 590 & 1,143 & 1,033 & 593 \\
\hline Fecal Coliforms & 8 & 5 & 3 & 2 & 11 & 56 & 30 & 31 & 38 & 44 & 11 & 7 \\
\hline E. coli Coliforms & $<1$ & $<1$ & $<1$ & $<1$ & 24 & 2 & 3 & $<1$ & $<1$ & 3 & 3 & $<1$ \\
\hline
\end{tabular}

2016 Data

\begin{tabular}{|l|c|c|c|c|c|c|c|c|c|c|c|c|}
\hline Analyte & Jan & Feb & Mar & Apr & May & Jun & Jul & Aug & Sep & Oct & Nov & Dec \\
\hline $\begin{array}{l}\text { Alkalinity } \\
\text { (mgCaCO }\end{array} \mathbf{\text { /L) }}$ & 40.0 & 30.0 & 32.0 & 13.3 & 40.0 & 40 & 40 & 40 & 20 & 20 & 15 & 20 \\
\hline Ammonia (mg/L) & 0.13 & 0.070 & 0.096 & 0.073 & 0.145 & 0.067 & 0.031 & 0.056 & 0.039 & 0.086 & 0.083 & 0.082 \\
\hline BOD (mg/L) & $<2.00$ & 3.76 & 5.88 & 2.51 & 4.55 & 3.74 & 4.02 & $<2.00$ & $<2.00$ & 2.4 & 2.36 & $<2.00$ \\
\hline Chloride (mg/L) & 0.94 & 0.39 & 0.12 & 0.10 & 1.0 & 0.34 & 0.20 & 0.60 & 0.0 & 0.0 & 0.0 & 0.2 \\
\hline Conductivity (uS/cm) & 43.1 & 43.9 & 36.9 & 44.2 & 33.8 & 34.6 & 35.8 & 36.0 & 27.8 & 34.6 & 33.5 & 31.6 \\
\hline $\begin{array}{l}\text { Dissolved Oxygen } \\
\text { (mg/L) }\end{array}$ & 9.88 & 9.92 & 8.39 & 9.35 & 7.83 & 7.66 & 6.64 & 7.11 & 7.76 & 7.99 & 8.35 & 9.71 \\
\hline
\end{tabular}


Gija Geme et al.

\begin{tabular}{|l|c|c|c|c|c|c|c|c|c|c|c|c|}
\hline \hline Nitrate (mg/L) & 0.63 & 0.98 & 0.36 & 0.6 & 0.6 & 0.6 & 0.5 & 1.0 & 0.6 & 0.6 & 0.5 & 0.4 \\
\hline pH (S.U.) & 7.01 & 7.63 & 7.15 & 7.12 & 7.06 & 7.17 & 7.09 & 6.91 & 6.93 & 6.59 & 6.59 & 6.66 \\
\hline Temperature ( $\left.{ }^{\mathbf{0}} \mathbf{C}\right)$ & 12 & 9 & 15 & 21 & 22 & 26 & 27 & 26 & 25 & 23 & 20 & 15 \\
\hline $\begin{array}{l}\text { Total Phosphorus } \\
(\mathbf{m g} / \mathbf{L})\end{array}$ & 0.07 & 0.06 & 0.11 & 0.08 & 0.11 & 0.12 & 0.1 & 0.08 & 0.08 & 0.09 & 0.0 & 0.2 \\
\hline Total Solids (mg/L) & 26.3 & 32.0 & 38.8 & 33.7 & 57.0 & 39.4 & 40.0 & 38.0 & 24.0 & 20.0 & 28.0 & 33.0 \\
\hline Turbidity(NTU) & 2.62 & 2.87 & 2.94 & 3.68 & 5.07 & 2.73 & 3.25 & 3.44 & 2.43 & 2.59 & 3.16 & 3.27 \\
\hline
\end{tabular}

\begin{tabular}{|l|c|c|c|c|c|c|c|c|c|c|c|c|}
\hline Analyte & Jan & Feb & Mar & Apr & May & Jun & Jul & Aug & Sep & Oct & Nov & Dec \\
\hline Total Coliforms & 303 & 818 & 1,592 & 1,080 & 1,310 & 978 & 645 & 745 & 752 & 948 & 763 & 693 \\
\hline Fecal Coliforms & 5 & 13 & 1 & 3 & 5 & 21 & 65 & 39 & 34 & 15 & 4 & 4 \\
\hline E. coli Coliforms & 2 & $<1$ & 4 & $<1$ & 7 & 10 & 10 & $<1$ & 2 & 5 & 5 & 3 \\
\hline
\end{tabular}

\section{Data Dissemination}

To better educate the local society of water quality, the data was submitted to the College of Science and Engineering for uploading on their website. The website is accessible to all of the students and public interested in water quality. The questions about interpretation of data can be addressed to the research center. Table 2 provides a snapshot of the website.

\section{Lake Columbia - Environmental Monitoring and Data}

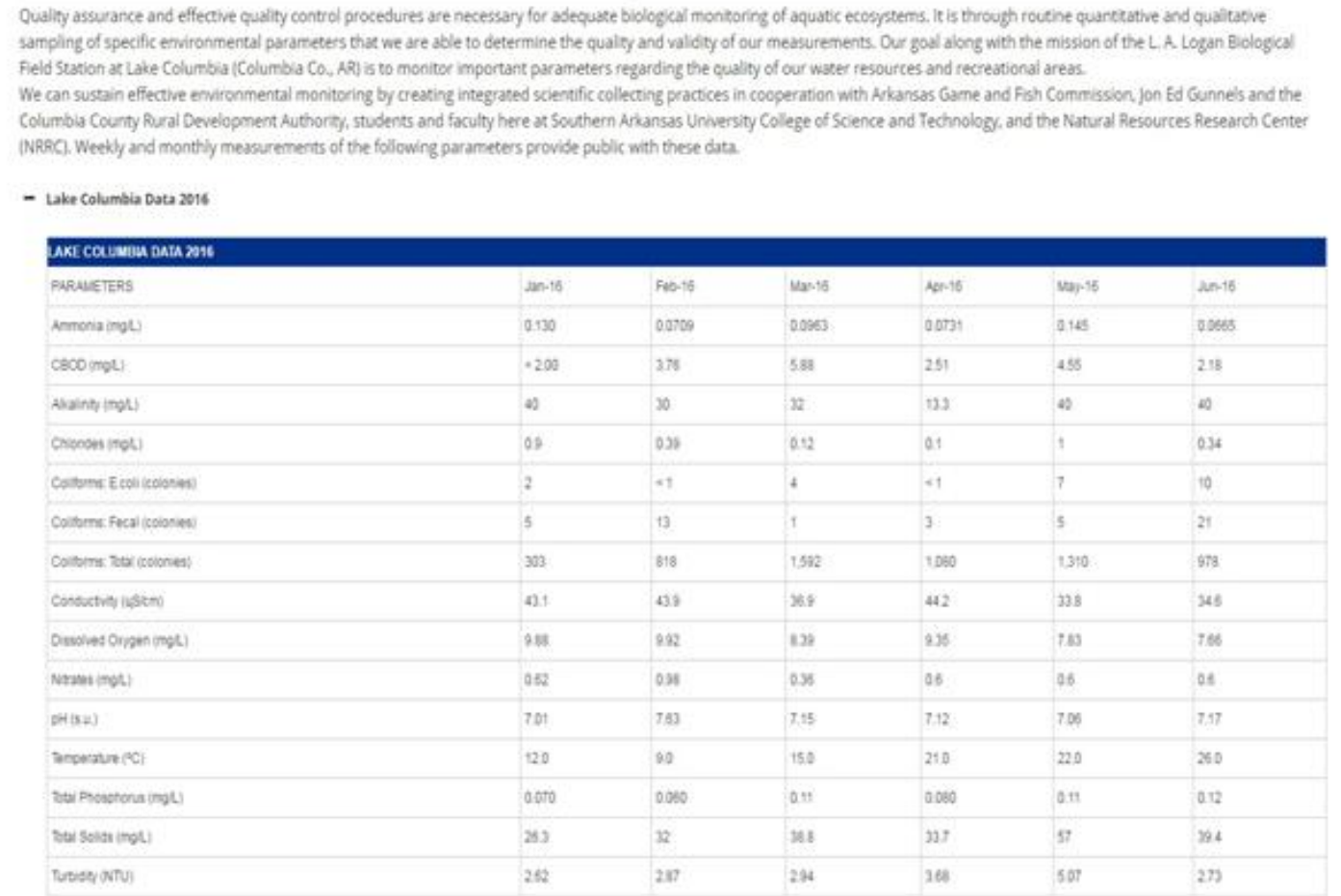

Figure1. The water data on SAU's website

\section{Conclusions}

The water samples from Lake Columbia were taken weekly for three years and the data was averaged and presented as monthly averages. The samples were analyzed for $\mathrm{pH}$, dissolved oxygen, nitrate and chloride ions, total phosphorus, total solids, bacteria (E.coli, total coliform, and fecal coliform), alkalinity, turbidity, conductivity, and ammonia.During the monitoring period, higher levels of bacteria was observed in summer months that could be a potential issue due to Lake Columbia being used for recreational purposes. This is also important since Lake Columbia is used as a potable water source and with inadequate disinfection, the bacteria can appear in consumer's tap water. The other parameters were consistent during 36 month period. With respect to other parameters, Lake Columbia can be considered a clean lake since it did have the acceptable levels of totals solids, alkalinity, $\mathrm{pH}$, dissolved oxygen, BOD, chlorides. Dissolved oxygen was significantly lower during summer, which is expected due to high water temperatures. However, adequate levels of dissolved oxygen needed for living organisms were observed in Lake Columbia. 
There were also correlations between totals solids and other ions in water. Due to the presence of higher concentrations of chloride and nitrate ions, higher concentrations of the total solids were observed in water, this trend was particularly observed during fall.

A very unique idea of this project was to disseminate data through an academic website thus reaching more potential readers and educated the society about the conditions of the local lake. This information could be very useful to the parents who take their young children for swimming in hot summer days.

\section{ACKNOWLEDGMENTS}

We acknowledge partial support from the Center for Advanced Surface Engineering, under the National Science Foundation Grant No. IIA-1457888 and the Arkansas EPSCoR Program, ASSET III.

\section{REFERENCES}

[1] Bhateria, R. \& Jain, D. Sustain. Water Resource Management 2016, 2:161.doi:10.1007/s408 99-015-0014-7

[2] Environmental Pollution Center. Retrieved from https://www.environment alpollutioncenters. org/water/

[3] Lake Columbia. Retrieved from https://www.arkansas.com/attractions/detail/lake-columbia/ 18871

[4] Rai, P. K.; Singh, M. M., Seasonal monitoring of water quality of a Ramsar site in an IndoBurma hotspot region of Manipur, India, International Research Journal of Environmental Sciences, 4 (4), 2015, 90-95.

[5] Ahiarakwem, Cosmas Ahamefule; Nwankwor, Godwin Ifedilichukwu; Iwuagwu, Chukwuma Julian; Ejike, Emmanuel Nnamdi; Onyekuru, Samuel Okechukwu, Water quality monitoring of a tropical lake and associated rivers: a case study of Oguta Lake and its tributaries, Niger delta basin, southeastern Nigeria,Journal of Environmental Science and Engineering A, 1 (6), 2012, 818-826.

[6] Hach Handbook of Water Analysis, $6^{\text {th }}$ Ed., 2012 Hach Chemical Company.

[7] Penn State Extension. Retrieved from http://extension.psu.edu/natural-resources/water/ponds/ pond-management/pond-construction/interpreting-water-tests-for-ponds-and-lakes

[8] B. Oram, Fecal Coliform Bacteria in Water, Water Research Center. Retrieved from http://www. water-research.net/index.php/fecal-coliform-bacteria-in-water

[9] APHA, AWWA, WEF. Standard Methods for the Examination of Water and Wastewater, $21^{\text {st }}$ Ed., 2005.

[10] B. Oram. The Role of alakilinit Citizen Monitoring. http://www.water-research.net/index.php/ the-role-of-alkalinity-citizen-monitoring

[11] Michaud, J.P. 1991. A citizen's guide to understanding and monitoring lakes and streams. Publ. \#94-149. Washington State Dept. of Ecology, Publications Office, Olympia, WA, USA (360) 407-7472.

[12] Molly Hunt, Elizabeth Herron and Linda Green, Chlorides in Fresh Water, URIWW 4, March 2012. 